\title{
THE EFFECTIVENESS OF TUNNEL SALT CONSTRUCTION IN PIDIE DISTRICT, ACEH
}

\author{
Athaillah Teuku*, Rahmi Suci \\ University of Teuku Umar, Indonesia \\ E-mail: athaillah.teuku@utu.ac.id
}

\begin{abstract}
The limitation in producing salt with a boiling mechanism is one of the technical obstacles for salt farmers. The construction of tunnel salt is an alternative to increase salt production. Therefore, research regarding the effectiveness of a salt tunnel construction in Pidie District is needed. This research is devoted to analyzing the effectiveness of the tunnel salt construction in Pidie District. The objects of this research are the parties involved in the manufacture of tunnel salt as well as traditional boiled salt farmers in Pidie District. The sampling technique used in this research is non-probability sampling using purposive sampling. The variables studied are the number of results achieved, the level of satisfaction obtained, and the intensity achieved. The number of results achieved: The maximum production capacity of tunnel salt per month is more than the maximum boiled salt production capacity. However, the price and average sales of tunnel salt per month are much lower than the boiled salt. The low price and average sales of tunnel salt cause the average income of tunnel salt farmers to get low as well. The level of satisfaction obtained: The quality of the entire tunnel and boiled salt in Pidie District nearly meet the standard of SNI3556: 2010. In terms of water content measurement, tunnel and boiled salt at le Lebeu Village were above $7 \%$ caused by the use factor of borehole water sources on the coastal mainland at le Leubeu Village. Intensity achieved: The tunnel salt making changes the salt production system starting from the brine cooking method to the drying process. When compared in terms of work, the construction of tunnel salt will make salt farmers much easier in producing the salt than using the boiled salt mechanism. Tunnel salt farmers will possess plenty of free time each day and only focuses on controlling water as well as checks the percent water salt content in the tunnel. They no longer need to spend much energy drying and transporting soil. Thus, the time and energy aspects of tunnel salt production are more efficient than the boiling mechanism.
\end{abstract}

\section{KEY WORDS}

Effectiveness, salt tunnel, boiled salt, results achieved, satisfaction, intensity.

The initial survey conducted by researchers in 2019 found that most salt farmers in Pidie area still produce salt by cooking or boiling traditionally. There are only 4 locations using tunnels in manufacturing salt, 2 locations are in Cebrek Village and the other 2 locations are in le Lebeu Village.

As an effort to increase salt production, the Pidie District Government is working with the Ministry of Maritime Affairs and Fisheries to build a tunnel salt production center as a pilot in Pidie District. There are 2 locations for the construction of salt tunnels, namely Cebrek Village and le Leubeu Village. The pilot tunnel has been operating since 2018.

Tunnel salt is dried salt in a closed model (tunnel). Tunnel salt is not dried directly. The process of making tunnel salt is by collecting sea / salty water and covering it with geothermal plastic. The advantage of this salt tunnel is that farmers can continue to produce salt even during the rainy season.

The more land is used to produce tunnel salt, the more salt farmers can produce. Unlike the production of boiled salt, the large area of production does not necessarily affect the amount of boiled salt production. Time greatly affects the production process of boiled salt, the farmers have to wait for 5 to 7 hours for one stew.

The limitation in producing salt with the boiling mechanism becomes one of the technical obstacles for the salt farmers. The construction of salt tunnels is an alternative to 
enhance salt production. Therefore, further research is needed concerning the effectiveness of the development and construction of salt tunnels in Pidie District.

\section{LITERATURE REVIEW}

Effectiveness is the achievement of goals precisely or choosing the right goals from a series of alternatives or way choices and making choices from several other options. Effectiveness can also be interpreted as a measurement of success in achieving predetermined goals (Damanik et al., 2014). According to Putri (2014), effectiveness is a successful implementation of predetermined targets. It simply means that if the activity results are closer to the target, the higher the effectiveness is. The effectiveness of the program can be identified by comparing the output with the program objectives, opinions of program participants can be used as a measure to determine the effectiveness of the program (Jibril, 2017).

There are two approaches to measuring effectiveness according to Tampubolon (2015), namely:

1. Achievement of Objectives Approach. The achievement of objectives approach is a measurement tool used to determine the success of an individual or group or even an institution. The results achieved are in the form of goods or services depending on the organization that produced them. This measure shows the capability of the organization to produce the needed output by society;

2. System Approach. The systems approach is an approach considering a system as a whole where it possessed several subsystems interrelated to one another. The systems approach not only emphasizes the final goal but also includes the overall criteria. In the systems approach, if one of the subsystems in it is disrupted or fails to be implemented, then the overall condition is deemed to be ineffective.

The program effectiveness can be considered to be an independent variable if it is not bound by other variables or unaffected variables causing changes or emergence of the dependent variable (bound). The sub-variables for program effectiveness are as follows:

- The number of results that can be issued;

- The level of satisfaction obtained;

- Creative products;

- The intensity to be achieved (Kristanto, 2013).

The tunnel salt making is conducted by extracting salt from seawater using natural evaporation methods with sunlight. The process starts from handling the intake of seawater (infusion to dirt deposition) to harvesting salt which lasts for approximately 1 (one) month (Mahdi, 2007). Salt making is done by a crystallization system and covered with geothermal plastic.

The increase in salt production has not been maximally carried out. Especially during the rainy season with unpredictable weather, which sometimes rain pours throughout the year causing salt production decreases drastically. This becomes a significant cause and obstacle to the salt farmers' income. For this reason, a breakthrough is needed so that salt production is not constrained by the rainy season (Soemargono, 2018). One of the breakthroughs needed is the production of tunnel salt.

\section{METHODS OF RESEARCH}

This research is devoted to analyzing the effectiveness of tunnel salt construction in Pidie District. The object of this research is the parties involved in the manufacture of tunnel salt as well as traditional boiled salt farmers in Pidie District. The scope of this research is limited to issues of the effectiveness of tunnel salt construction in Pidie District, Aceh.

The sampling technique used in this study is non-probability sampling using purposive sampling. Samples taken include farmers who have produced tunnel salt and farmers who reside around tunnel salt-making location but still produce boiled salt as well. 
The data used in this research are primary data. Primary data were collected by researchers by conducting observations and direct interviews with salt farmers in Pidie District. The data were analyzed in a descriptive-quantitative, namely a complete picture analysis of the effectiveness of tunnel salt construction in Pidie District. The indicators of the variables to be studied are as follows:

Table 1 - Indicators of the variables studied

\begin{tabular}{|l|l|l|l|}
\hline No & Variables & Sub Variables & Indicators \\
\hline 1 & The Effectiveness of & The number of results achieved & 1. Production Capacity \\
& Tunnel salt Construction & & 2. Product Price \\
& & 3. Product Sales \\
& & 4. Salt Farmers' Income \\
\cline { 3 - 4 } & & & The level of satisfaction obtained \\
& & 1. Output Quality / Salt \\
& & 2. Fullfillment of Market Needs \\
\cline { 3 - 4 } & The intensity to be achieved & 3. Salt Farmers' response \\
\hline
\end{tabular}

\section{RESULTS AND DISCUSSION}

Boiled salt is the salt produced by the boiling process of brine using firewood. The process for making boiled salt is as follows:

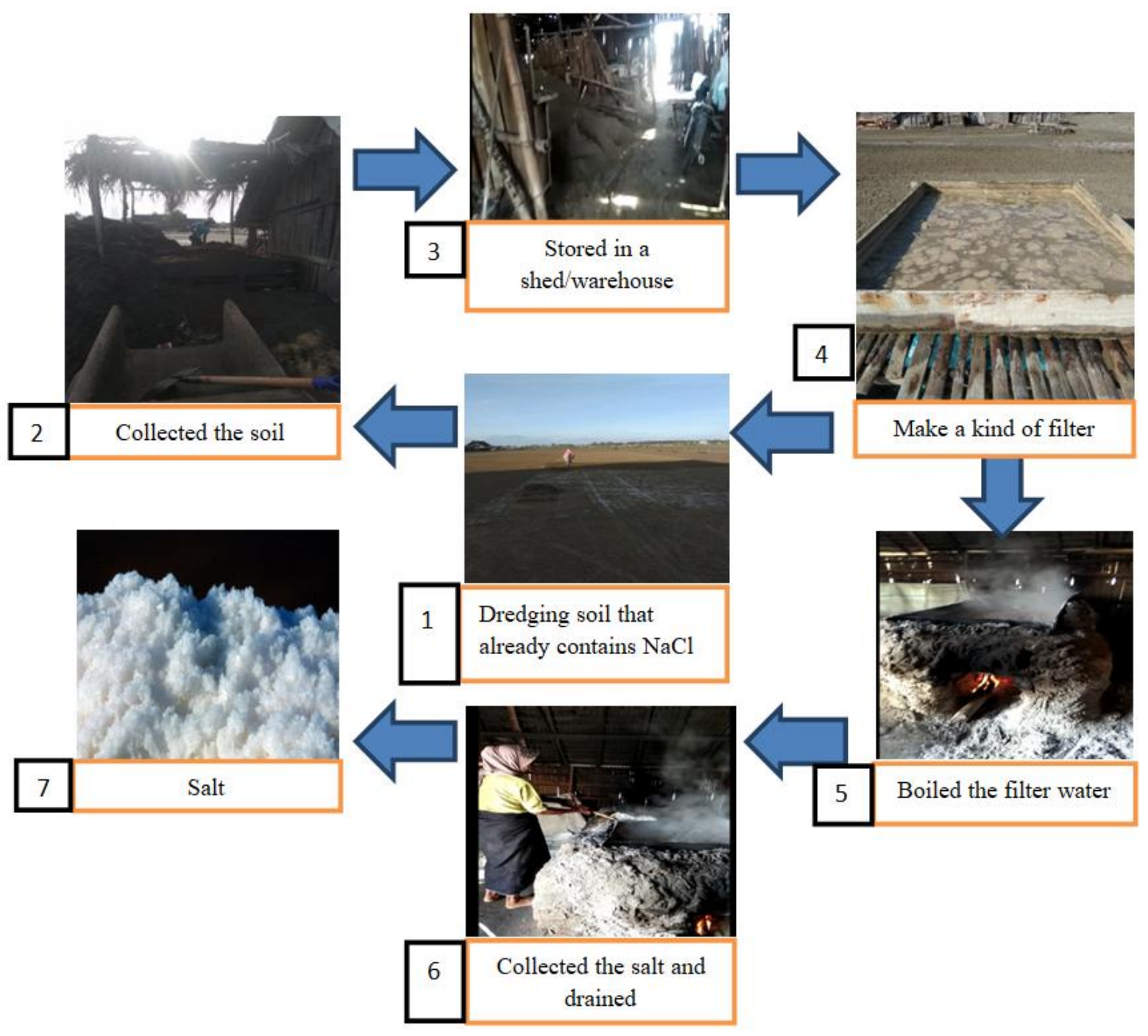

Figure 1 - The Process of Making Boiled Salt 
Figure 1, shows the process of making boiled salt is 1) Dredging / drying the soil/ evaporation process. 2) Collecting the dried soil in the sun or the soil that has gone through the evaporation process. 3) Storage of dried soil in the warehouse. 4) Watering the dried soil in the sun with salty water and then the water is taken. 5) The process of cooking water from the watering. 6) The process of removing and draining the salt. 7) The making salt process is finished.

In order to make boiled salt, farmers need a container (pot), a stove, firewood, a water filter and a hut/storage house. The process of boiling salt water takes 5 to 7 hours to turn into salt. Farmers produce 80 to $100 \mathrm{~kg}$ of salt for a single cook depending on the size of the kitchen used and the salt content in the cooking water. Farmers can produce a maximum of $200 \mathrm{~kg}$ of cooking kitchen salt in a day for 2 stews.

Tunnel salt is the salt dried in a closed model (tunnel). The process of making tunnel salt is by collecting sea / salty water in a geomembrane plastic and covering it with geothermal plastic. Here is the process for making tunnel salt:

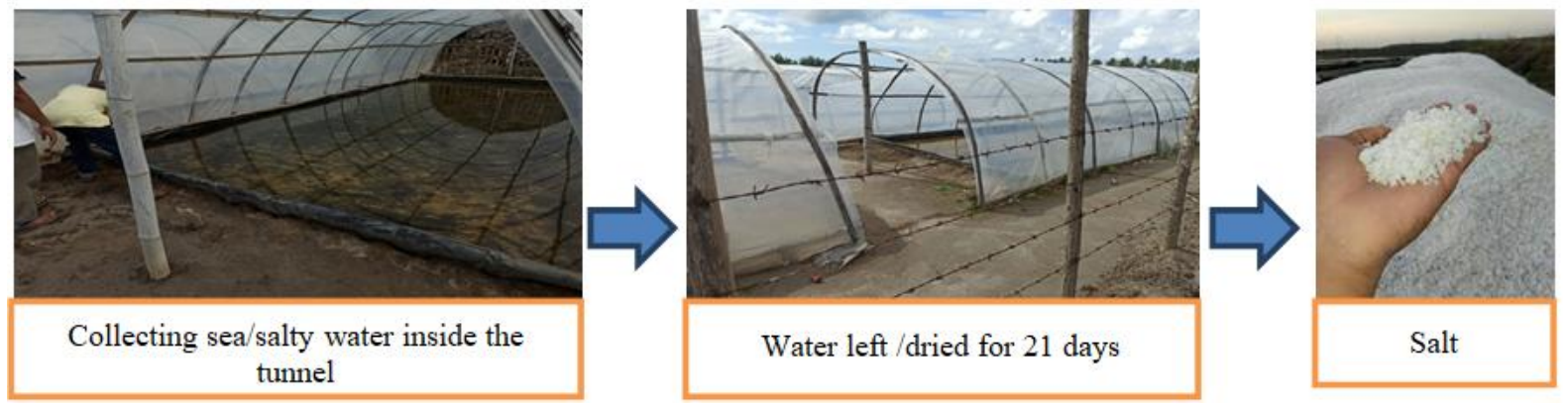

Figure 2 - The procces of Making Tunnel Salt

Figure 2, shows the process of making tunnel salt in Pidie District at Cebrek and le Lebeu Villages, namely: 1) Storing salty water coming from the sea or a borehole into geomembrane plastic. Water is usually flowed using a machine. 2) Water is collected and dried in the tunnel until it turns into salt for 21 days. 3) Salt can be collected from the tunnel and ready to be sold. The following is the comparison between tunnel salt and boiled salt for the number of results achieved:

Table 2 - Comparison of Tunnel Salt and Boiled Salt on Total Results Achieved

\begin{tabular}{|l|l|l|l|l|}
\hline No & Item Comparison & Arable Land Area & Boiled Salt & Tunnel Salt \\
\hline 1 & Maximum Production Capacity / Month & 350 meters & $6.000 \mathrm{~kg}$ & $7.140 \mathrm{~kg}$ \\
\hline 2 & Product Price & - & $\mathrm{Rp} 4.000 / \mathrm{kg}$ & $\mathrm{Rp} 2.000 / \mathrm{kg}$ \\
\hline 3 & Average Product Sales /farmer/ month & 350 meters & $2.500 \mathrm{~kg}$ & $1.000 \mathrm{~kg}$ \\
\hline 4 & Average Farmers' Income/ month & 350 meters & $\mathrm{Rp} 3.400 .000$ & $\mathrm{Rp} 400.000$ \\
\hline
\end{tabular}

For the manufacture of tunnel salt, farmers can produce a maximum of $500 \mathrm{~kg} / \mathrm{tunnel}$ with a tunnel area of $4 \times 8$ meters in 21 days. Boiled salt farmers possess an average land area of 350 meters for scratching. If the land is converted to making tunnels, farmers can build an average of 10 tunnels/farmer. By building 10 tunnels, the farmers can produce a maximum of 5 tons of salt $/ 21$ days. Meaning, farmers can produce $238 \mathrm{~kg}$ of salt per day.

The price of boiled salt sold to industrial agents worth Rp. 4.000 per $\mathrm{kg}$ while the retail price to buyers coming directly to the manufacture location is Rp. 6.000 . Buyers will get a discount like an agent if they buy in large quantities, while the selling price of tunnel salt is only IDR $2.000 / \mathrm{kg}$. The tunnel salt is usually sold to ice cream makers and boiled salt farmers who use it to increase the salt content of boiled salt production.

Tunnel salt production in Pidie District reaches 5 tons/month. It is surely a huge production capacity but having not accompanied by adequate distribution channels to marketing turns in into a big obstacle for the tunnel salt farmers. This technical constraint causes tunnel salt farmers to store their tunnel salt production in warehouses for a long time, 
while the storage capacity of farmers is completely limited. Tunnel salt farmers can only sell an average of 1 ton of salt / month.

Meanwhile, boiled salt is easier to sell in marketing since it is widely used by the community to meet the need for additional flavors of foodstuffs. The production of boiled salt is distributed by agents to communities around Pidie District and to other areas. In addition, the distribution of boiled salt is also supplied to agents who have been bound by contracts during the process of handling raw materials into salt, farmers usually conduct debt / receivable transactions with agents in managing operational costs of salt processing. The farmers produce boiled salt and sell it for an average of 2,5 tons/month though they are able to produce a maximum of up to 6 tons of salt/month.

The average income of boiled salt farmers is Rp. 3.400 .000 per month. The income is obtained from the number of sales multiplied by the selling price and reduction of variable costs (firewood) and fixed costs (huts for boiling and storing salt, pots, earthen drying equipment and water machines. Meanwhile, the average monthly income of the tunnel salt farmers is only Rp. 400.000 which is obtained from the number of sales multiplied by the selling price of fixed costs (geomembrane plastics, geothermal plastics and water machines). The high fixed costs of geomembrane and geothermal plastic raw materials reached Rp. 4.000.000/tunnel without maximum sales and low salt prices, making the farmers' income considerably low.

Cebrek and le Leubeu Villages are two of the villages in Pidie District, Aceh Province, which are the centers of salt production. The results of salt production in Pidie District have great potential in meeting the needs of food and industrial raw materials. The electrolyte content in salt is truly beneficial for the human body so that production techniques, quality of iodized salt consumption, supply, salt distribution chain and responsibility of salt farmers are the main criteria in measuring the level of satisfaction on the variables that ensure the construction of tunnel salt in Pidie District. Table 3 shows the salt quality results with tunnel and boiling system.

Table 3 - Salt quality with tunnel and boiling mechanism

\begin{tabular}{|c|c|c|c|c|c|c|}
\hline \multirow{3}{*}{ Quality Test } & \multicolumn{6}{|c|}{ Salt Observation Results } \\
\hline & \multicolumn{4}{|c|}{ Tunnel } & \multicolumn{2}{|l|}{ Boiling } \\
\hline & $\begin{array}{l}\text { Cebrek } \\
\text { Village I }\end{array}$ & $\begin{array}{l}\text { Cebrek } \\
\text { Village II }\end{array}$ & $\begin{array}{l}\text { le Leubeu } \\
\text { Village I }\end{array}$ & $\begin{array}{l}\text { le Leubeu } \\
\text { Village II }\end{array}$ & $\begin{array}{l}\text { Cebrek } \\
\text { Village }\end{array}$ & $\begin{array}{l}\text { le Leubeu } \\
\text { Village }\end{array}$ \\
\hline Water content (\%) & 4,22 & 6,99 & 1,38 & 7,14 & 3,82 & 7,49 \\
\hline $\mathrm{NaCl}$ content (\%) & 95,64 & 96,73 & 96,56 & 94,13 & 97,06 & 97,39 \\
\hline $\begin{array}{l}\text { Potassium iodide } \\
\left(\mathrm{KIO}_{3}\right)(\mathrm{mg} / \mathrm{kg})\end{array}$ & 38,01 & 42,17 & 42,5 & 42,77 & 45,43 & 46,94 \\
\hline
\end{tabular}

Based on Table 3, it indicates that the percentage parameter of the average water content either by using a tunnel or boiling at Cebrek and le Leubeu villages in Pidie District ranges from $1,38 \%-6,99 \%$. This percentage has met the quality requirements of the Indonesian National Standard (SNI) which is smaller $<7 \%$. However, there were two observation villages on the watch, the tunnel salt was observed at le Leubeu II and boiled salt was taken cared at le leubeu village obtaining a percentage of water content above $7 \%$. This is influenced by the factor of using borehole water source as a material for making salt on the coastal land at le Leubeu Village, while the parameters of sodium chloride $(\mathrm{NaCl})$ in both tunnel and boiled salt meet the quality requirements (SNI 3556: 2010), average levels of sodium chloride $(\mathrm{NaCl})$ with tunnel and boiling mechanism at Cebrek and le Leubeu Villages, Pidie District were greater than the quality standard namely $>94 \%$. Likewise, the quality of iodized salt consumption (iodine content as potassium iodate (KIO3)) meets the quality standard requirements of an average greater than $30 \mathrm{mg} / \mathrm{kg}$ (Table 4). According to the Indonesian National Standard (SNI 3556: 2010), iodized salt consumption is a standard setting for salt produced by farmers in Indonesia with the aim of protecting consumer health, ensuring an honest and responsible food trade, and supporting the development and diversification of iodized salt consumption industry products. Table 4 shows the requirements for the quality of iodized salt consumption. 
Table 4 - Quality requirements of iodized salt consumption

\begin{tabular}{|l|l|l|l|}
\hline No. & Types of Test & Unit & Requirements \\
\hline 1 & Water content (H2O) & $\%$ & $\operatorname{max.7}$ \\
\hline 2 & $\begin{array}{l}\text { NaCl content (natrium chloride) calculated from the number of } \\
\text { chloride (Cl-) }\end{array}$ & $\%$ & $\operatorname{min~} 94$ \\
\hline 3 & Water-insoluble parts & $\%$ & $\max .0,5$ \\
\hline 4 & lodine is calculated as Potassium iodide (KIO3) & $\mathrm{mg} / \mathrm{kg}$ & $\min .30$ \\
\hline 5 & $\begin{array}{l}\text { Metal contamination: } \\
- \text { Cadmium }(\mathrm{Cd}) \\
- \text { Lead (Pb) } \\
- \text { Mercury }(\mathrm{Hg})\end{array}$ & $\begin{array}{l}\mathrm{mg} / \mathrm{kg} \\
\mathrm{mg} / \mathrm{kg} \\
\mathrm{mg} / \mathrm{kg}\end{array}$ & $\begin{array}{l}\max .0,5 \\
\max .10,0 \\
\max .0,1\end{array}$ \\
\hline 6 & Arsenic Contamination (As) & $\mathrm{mg} / \mathrm{kg}$ & $\operatorname{max.0,1}$ \\
\hline
\end{tabular}

Source: (SNI 3556: 2010).

Table 4 illustrates that there is a quality determination of salt in Indonesia. Standard iodized salt for consumption is a food product whose main component is sodium chloride $(\mathrm{NaCl})$ with the addition of potassium iodate (KIO3). So that the overall result of salt production at Cebrek and le Leubeu villages, Pidie District has met the quality standards (SNI 3556: 2010).

The salt production center in Pidie District can be affected by production capacity, product prices, marketing capacity and the average income of salt pond farmers. Table 2 shows that in terms of salt production capacity, the salt production using the tunnel system obtained a greater quantity than using the boiling system. This describes that in terms of production capacity, salt with a tunnel system provides effectiveness in meeting market needs on a large scale of $7.140 \mathrm{~kg} / \mathrm{month}$, both to meet community needs and industrial raw materials. In terms of the product price, tunnel salt production provides a more affordable price per kilogram of salt. This indicates that in an effort to meet the large-scale needs of industrial raw materials, the distribution of salt production using the tunnel system is considered optimal and efficient in meeting market needs.

In addition, the yield of tunnel salt is lower than that of the boiling system in terms of marketing capacity. This is affected by the absence of salt supply chain standards both in meeting people's food needs and as industrial raw materials, as the result, these parameters will affect the average income margins of salt farmers at Cebrek and le Leubeu Villages, Pidie District. The profit from salt production is obtained from the profitability ratio in the selling activities of salt production. The greater the scale of the tunnel system salt sales from the production per / month, the higher the average income that the tunnel system salt farmers will obtain.

Due to the relatively small market demand, boiled salt farmers respond to the market by stopping production if the salt stock has not been sold out in storage, so do the tunnel-salt farmers. They will also stop working as long as the warehouse is full of tunnel salt production.
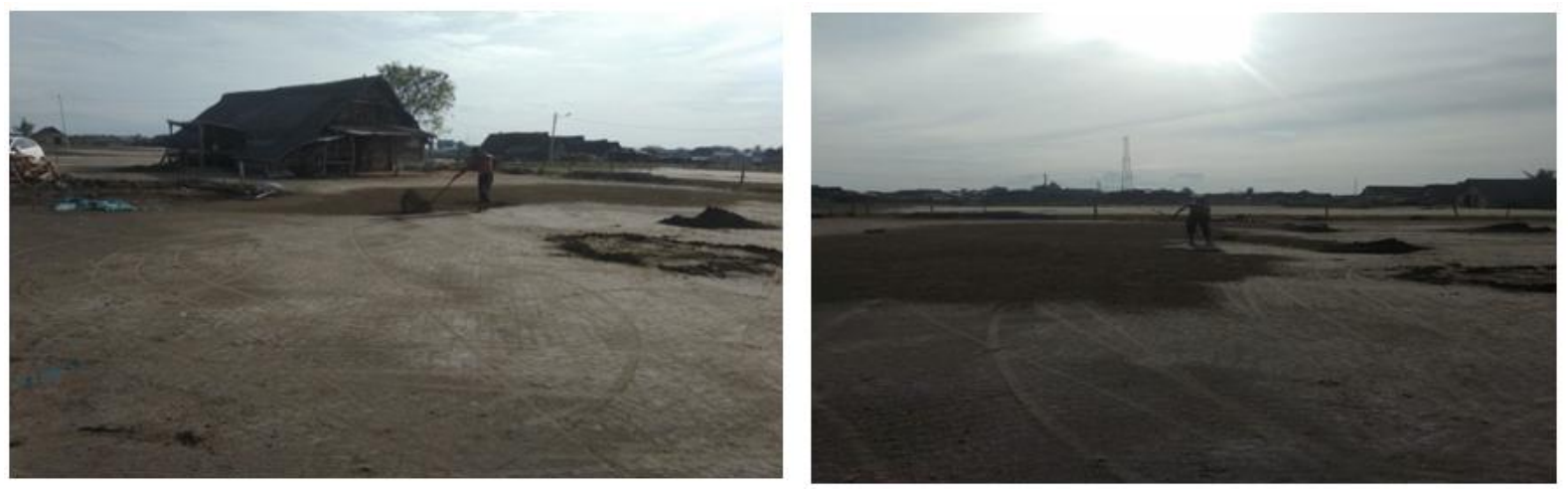

Figure 3 - The soil drying process for raw material of boiled salt 
Tunnel salt making changes the salt production system from the brine cooking method to the drying process. In terms of the perspective of work, the making of tunnel salt is much easier than boiled salt for salt farmers. Tunnel salt farmers only need to fill the salty water (sea or borehole) into the plastic geomembrane covered by the tunnel and then wait for the salt to be taking form for 21 days (Figure 2).

The making of boiled salt requires energy optimization for drying, scratching and transporting the soil. All the work is done manually by salt farmers for a full day. Farmers usually start scratching soil in the morning, then wait for the evaporation process with the aid of sunlight evaporating the water into the air and leaving $\mathrm{NaCl}$ in the scratched soil. The contained- $\mathrm{NaCl}$ soil is then taken to the filtering spot and doused with sea / salty water. The water from that watering is later boiled into salt. Meanwhile, the unused scratched soil can be transported and stored in a storage hut, usually for 3 days of use.

Tunnel salt farmers possess much leisure time every day. They only focus on controlling water and checking the percentage of water salt content in the tunnel as daily activities. They no longer need to spend a lot of energy to dry and to transport the soil. Hence, the working time of tunnel salt farmers is much shorter and can be used to make a living elsewhere.

\section{CONCLUSION}

The number of results achieved: The maximum production capacity of tunnel salt per month is greater than that of production capacity of boiled salt. However, the price and the average sales of tunnel salt / month are much lower than boiled salt. The low price and average sales cause tunnel salt farmers' average income to be low.

The level of satisfaction obtained: The quality of the whole tunnel and boiled salt in Pidie District nearly meet the SNI3556: 2010 standards. The minus is only on the measurement of water content, tunnel and boiled salt at le Lebeu Village which was above $7 \%$ caused by the factor of using borehole water sources on the coastal mainland at le Leubeu Village.

Intensity achieved: The tunnel salt making changes the salt production system from the brine cooking method to the drying process. When compared from the perspective of work, the making of tunnel salt is much easier than boiled salt for salt farmers. Tunnel salt farmers have plenty of free time each day. They only control water and check the percentage of the water-salt content in the tunnel. They no longer need to spend a lot of energy drying and hauling soil. Thus, their working time is much shorter and can be used to make a living elsewhere.

\section{ACKNOWLEDGMENTS}

This research is funded by Direktorat Riset dan Pengabdian Masyarakat, Deputi Bidang Penguatan Riset dan Pengembangan, Kementerian Riset dan Teknologi / Badan Riset dan Inovasi Nasional, Indonesia.

\section{REFERENCES}

1. Damanik R F, Supriana T, Sebayang T.2014. Analisis Efektivitas Distribusi Beras Miskin (Raskin) (Studi Kasus: Kelurahan Tanjung Marulak Kecamatan Rambutan, Kota Tebing Tinggi). (The Analysis of the Effectiveness of Subsidized Rice Distribution, Case Study: Tanjung Marulak Village, Rambutan Sub-district, Tebing Tinggi Municipality) Journal On Social Economic Of Agriculture And Agribusiness. Vol. 3 No. 2.

2. Jibril. A. 2017. Efektivitas Program Perpuseru Di Perpustakan Umum Kabupaten Pamekasan. (The Effectiveness of Perpuseru Program at Public Library of Pamekasan District) Journal of Universitas Airlangga. Vol. 6 No. 2.

3. Kristanto J. 2013. Efektivitas Program Dana Bergulir Bagi Ukm Dalam Pemberdayaan Ekonomi (Studi Pada UKM Binaan Dinas Koperasi, Kota Surabaya). (The Effectiveness 
of Revolving Fund Program for SMEs in Economic Empowerment (Study of SMEs Assisted by the Cooperative Office, Surabaya City) Journal of Publika. Vol. 1 No. 2.

4. Mahdi, A. 2007. Upaya peningkatan produksi dan kualitas garam nasional (Efforts to increase the production and quality of national salt). http://portal.bumn.go.id/

5. Putri N.E. 2014. Efektivitas Penerapan Jaminan Kesehatan Nasional Melalui BPJS dalam Pelayanan Kesehatan Masyarakat Miskin di Kota Padang (The Effectiveness of the Implementation of National Health Insurance through BPJS in Health Services for the Poor in Padang). TINGKAP. Vol. 10 No. 2.

6. Soemargono dan Widodo L U. 2018. Metode Mempercepat Pembuatan Garam Rakyat (Method of Accelerating People's Salt Making). Jurnal Teknik Kimia (Journal of Chemical Engineering). Vol. 12 No. 2.

7. Tampubolon.2015. Efektivitas Pengawasan Keselamatan dan Kesehatan Kerja Oleh Dinas Sosial dan Tenaga Kerja Kabupaten Sidoarjo sebagai Upaya Mewujudkan Budaya K3 (The Effectiveness of Occupational Safety and Health Supervision by the Office of Social Affairs and Manpower in Sidoarjo Regency as an Effort to Create a K3 Culture). Kebijakan dan Manajemen Publik (Policy and Public Management).Vol. 3 No. 3.

8. Yuliana U. 2019. Peningkatan Kualitas produksi Garam Menggunakan Teknologi Geomembran (Improving the quality of salt production using geomembrane technology). Jurnal Studi Manajemen dan Bisnis (Journal of Management and Business Studies). Vol. 6(2) hlm (page) 35-42. 